\title{
The Effects of Cropping Methods on Growth, Crop Index and Yield Response to Water of Rice (Oryza sativa L.) in Rainfed Agriculture
}

\author{
Bayu Dwi Apri Nugroho and Rizki Maftukhah \\ Department of Agricultural Engineering and Biosystem, Faculty of Agricultural Technology, Gadjah Mada University, Yogyakarta \\ 55281, Indonesia
}

\begin{abstract}
In this study, four combinations of crops: rice (C), rice-maize (MCS1), rice-cassava (MCS2) and rice-maize-cassava (MCS3) with $3 \mathrm{~m} \times 3 \mathrm{~m}$ each plots at two field areas-Saptosari and Tanjungsari were observed. Both field areas are located in Gunungkidul district, South-Central of Java Island, with that $93 \%$ at those areas are $185 \mathrm{~m}$ to $500 \mathrm{~m}$ above sea level and high proportion of multiple cropping systems (MCS). The aim of this study was to investigate the effect of different cropping method on growth, crop index and yield response to water of rice in rainfed agriculture. Mathematical models were developed to describe rice growth. The rice height was followed monomolecular function and the number of tillers followed exponential polynomial function. Crop index was calculated from climate data during plant growth phase. And yield response to water was calculated from actual evapotranspiration $(E T a)$ and the maximum evapotranspiration $(E T m)$. The results showed that the height of rice was not significantly different between each combination $(P>0.05)$. Number of tillers was also not significant $(P>0.05)$. However, monoculture treatment had more number of tillers than rice in MCS. Crop index of rice at Saptosari was higher than at Tanjungsari. Based on the calculation of evapotranspiration $(E T)$, water deficit at initial was less than at mid-season $(E T a<E T m)$ and affected water stress. Statistical analysis showed that cropping methods did not significantly affect rice growth and yield $(P>0.05)$.
\end{abstract}

Key words: Rice, rainfed agriculture, growth, crop index, yield.

\section{Introduction}

In Indonesia, rice is planted early in the "wet season" between September and December, when there is sufficient moisture to prepare the land for cultivation and to facilitate early rooting of rice seedlings [1]. In this case, the exact timing of wet season may vary from year to year more than one month, depending on rainfall distribution pattern.

Water is the key driver of rice cultivation and its supply in adequate quantity is one of the most important factors in rice production [2, 3]. Variability of rainfall is the main problem of agriculture at highland fields, which is caused by unpredicted water due to less amount of rainfall. According to Hoogenboom [4], the soil can not hold the rainwater

Corresponding author: Bayu Dwi Apri Nugroho, Ph.D., research field: agroclimatology. adequately due to the soil profile. To know the effect of water on production, the evapotranspiration (ET) can be calculated. If the water availability is insufficient to meet the water requirement of plant, actual evapotranspiration (ETa) will decrease under the maximum evapotranspiration $(E T m)$ or ETa < ETm. This condition will develop water stress and negatively affect rice growth and yield [5].

To increase the land productivity, improving cropping system management has been identified [6]. Farmers in Indonesia, particularly South-Central of Java, commonly use multiple cropping system (MCS) for efficiency purposes. MCS is a system where multiple crops are planted on the same field, but not simultaneously, during a season [6]. This system will affect rice yield. 
In addition, climate is one of the key factors that affect rice cultivation. Commonly, crop cycle is not only the change of quantitative growth, but also the development stage (phenology) of plant [7]. Crop phenology plays an important role in crop development and yield [8, 9]. Crop phenology describes the effect of climate on plant development, which is calculated by crop index [10].

Therefore, the aim of this study was to investigate the effect of different cropping methods on growth, crop index and yield response to water of rice in rainfed agriculture.

\section{Materials and Methods}

\subsection{Experimental Site}

Experiments were conducted at Saptosari and Tanjungsari sub-districts (Fig. 1), which are located at highland agriculture. The $93 \%$ of the study areas have altitude of $185 \mathrm{~m}$ to $500 \mathrm{~m}$ above sea level and high proportion of MCS [11]. The mean annual rainfall was 1,400 $\mathrm{mm}$ for Saptosari and 1,700 $\mathrm{mm}$ for Tanjungsari during rainy season based on the record data from 1989-1998 [12].

Fig. 2 shows the cropping patterns in Saptosari and

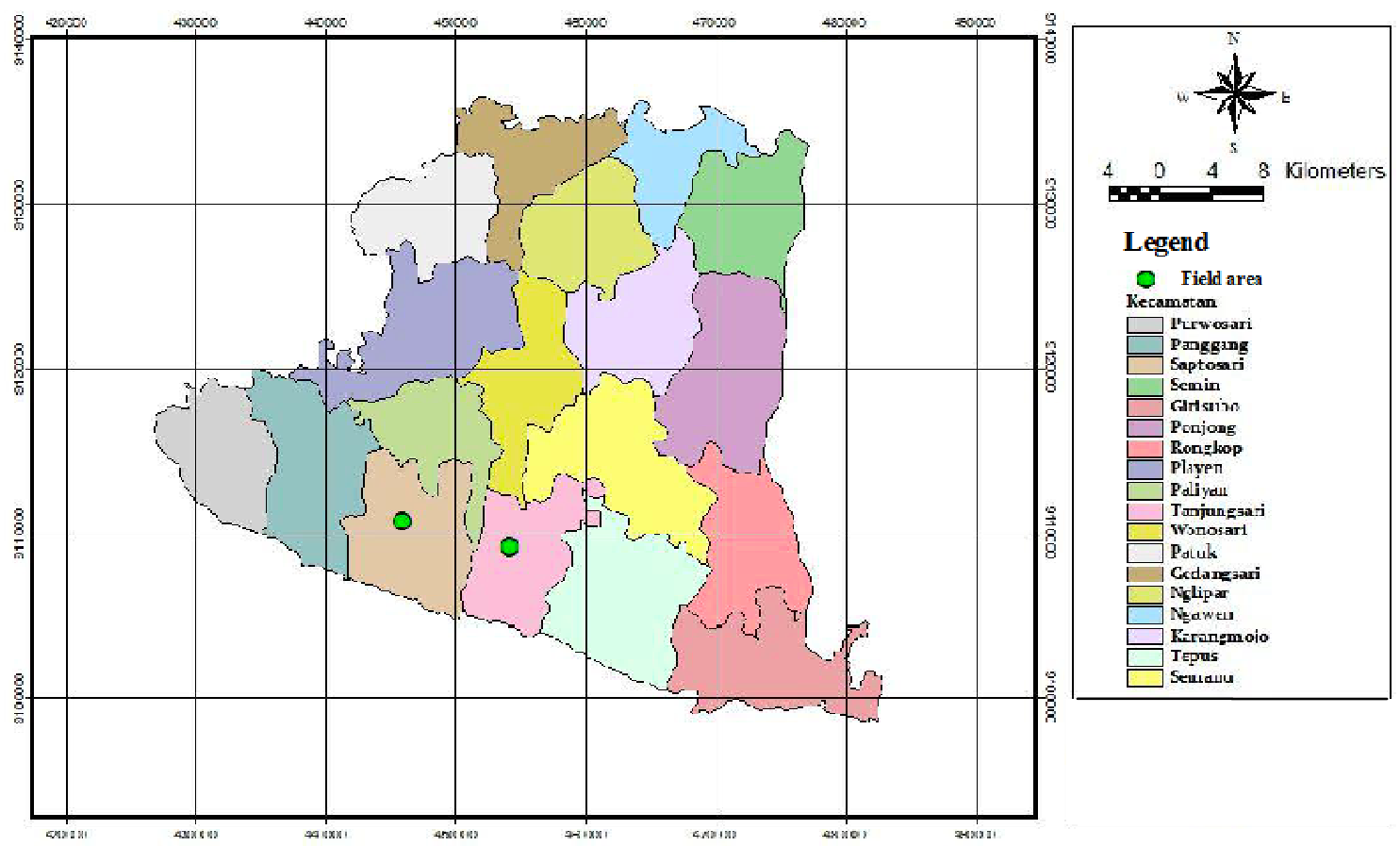

Fig. 1 The sub-districts in Gunungkidul district and location of Saptosari and Tanjungsari (green dot).

\begin{tabular}{|c|c|c|c|c|c|c|c|c|c|c|c|}
\hline \multicolumn{6}{|c|}{ Rainy season } & \multicolumn{6}{|c|}{ Dry season } \\
\hline Nov & Dec & Jan & Feb & Mar & Apr & May & Jun & Jul & Aug & Sep & Oct \\
\hline \multicolumn{12}{|c|}{ Maize } \\
\hline \multicolumn{4}{|c|}{ Dryland rice } & \multicolumn{4}{|c|}{ Peanut } & \multicolumn{4}{|c|}{ Peanut } \\
\hline \multicolumn{12}{|c|}{ Cassava } \\
\hline \multicolumn{12}{|c|}{ Cropping pattern $\mathrm{A}$} \\
\hline \multicolumn{4}{|c|}{ Maize } & & & & & & & & \\
\hline \multicolumn{5}{|c|}{ Peanut } & \multicolumn{3}{|c|}{ Soybean } & \multicolumn{4}{|c|}{ Peanut } \\
\hline \multicolumn{12}{|c|}{ Cassava } \\
\hline \multicolumn{12}{|c|}{ Cropping pattern B } \\
\hline
\end{tabular}

Fig. 2 Cropping patterns at Saptosari and Tanjungsari during one year [11]. 
Tanjungsari [11]. Combination of maize-dryland rice-cassava and maize-peanut-cassava are planted first at the beginning of the rainy season, and combination of peanut-cassava and soybean-cassava follows the next planting season.

\subsection{Experimental Design and Data Analysis}

The experiment was laid out in a randomized complete block design (RCBD) with three replicates according to Gomez, K. A. and Gomez, A. A. [13]. The treatments used were-control: rice monoculture (C); rice-multiple cropping: rice + maize (MCS1); rice-multiple cropping: rice + cassava (MCS2); rice-multiple cropping: rice + maize + cassava (MCS3).

The seeds of rice, maize and cassava were planted together in each plot with different planting dates during cropping season from September to February. The difference of planting dates is caused by local tradition and decision of farmer in each field areas. Crop samples (five samples in each plot) were taken periodically every $10 \mathrm{~d}$ during the plant growth stages. Fertilizer and organic nutrient were used in this study by referring local schedule of the farmers in each field areas.

To analyze the height of rice, monomolecular equation was used as stated by Murtiningrum et al. [14], if the growth of rice will be plotted in the graph, it will follow monomolecular equations as expresses in Eq. (1):

$$
\ln =\left(\frac{T f-T o}{T f-T}\right)=k t
$$

where, $T_{f}$ is the height of rice in the harvesting, $T_{o}$ is the height of rice seed in the beginning of planting, and $T$ is the height of rice at day of observation.

And for the number of tillers, the exponential polynomial equation is used as Eq. (2):

$$
A=\exp \left(\mathrm{a}_{0}+\mathrm{a}_{1} t+\mathrm{a}_{2} t^{2}\right)
$$

where, $A$ is the number of tillers.

Crop index $(M)$ is determined by Eq. (3), which was developed by Pusposutardjo [10].

$$
M=\left[\frac{\sum_{t=0}^{S j}(R s) t}{\sum_{t=0}^{S j}(\text { Tav }) t}\right]+\left[\sum_{t=0}^{S j}(\operatorname{Tmin}) t\right]^{0.7}
$$

where, $M$ is plant development indicator during growth phase (crop index); $S j$ is growth period in every growth phase; $t$ is time of plant growth (day); $R s$ is daily radiation $\left(\mathrm{cal} / \mathrm{cm}^{2} /\right.$ day); Tav is daily average temperature $\left({ }^{\circ} \mathrm{C}\right)$; $\quad \operatorname{Tmin}$ is the daily minimum temperature $\left({ }^{\circ} \mathrm{C}\right)$.

To analyze yield response to water, the ETa and ETm was calculated. ETa could be estimated from data on evapotranspiration rate, available soil water and wetting intervals [3]. In this study, ETa was also calculated by Aquacrop software based on daily water balance calculations. ETm was calculated as Eq. (4):

$$
E T m=k_{c} \times E T o
$$

where, ETo is evapotranspiration and $k_{c}$ is crop coefficient. The parameters needed for Aquacrop to calculate ETa were shown in Table 1.

Also, to analyze the homogeneity data and the significantly of the plant growth and yield, analysis of variance (ANOVA) was carried out according to Gomez, K. A. and Gomez, A. A. [13].

\section{Results and Discussion}

\subsection{Modeling of Plant Height and Number of Tillers}

\subsubsection{Plant Height of Rice}

The result of the height in rice was plotted in the graph using monomolecular equation as shown in Fig. 3. The plant height had almost similar value among all treatments.

Table 1 Data parameters of Aquacrop.

\begin{tabular}{ll}
\hline Variable & Parameters \\
\hline \multirow{2}{*}{ Climate } & Daily rain \\
& Daily temperature (max and min) \\
& Daily evapotranspiration (ETo) \\
\hline \multirow{4}{*}{ Soil } & Depth of soil \\
& Field capacity \\
& Wilting point \\
& Bulk density \\
& Specific density \\
\hline \multirow{2}{*}{ Crop } & Crop type \\
& Date of planting \\
& Date of harvesting \\
\hline
\end{tabular}




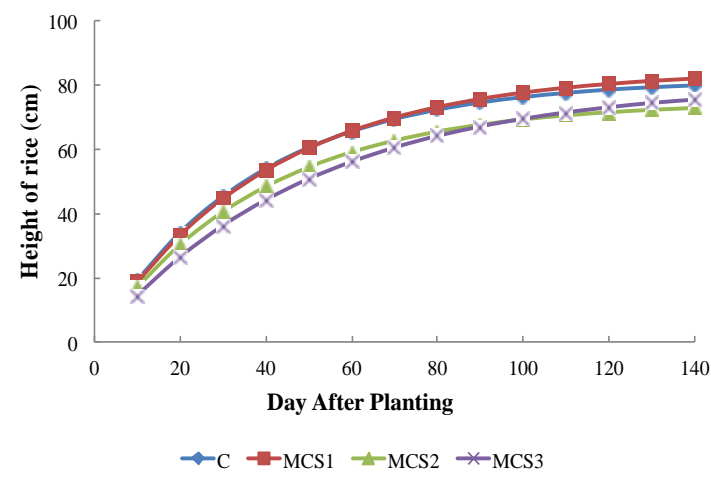

(a) Saptosari

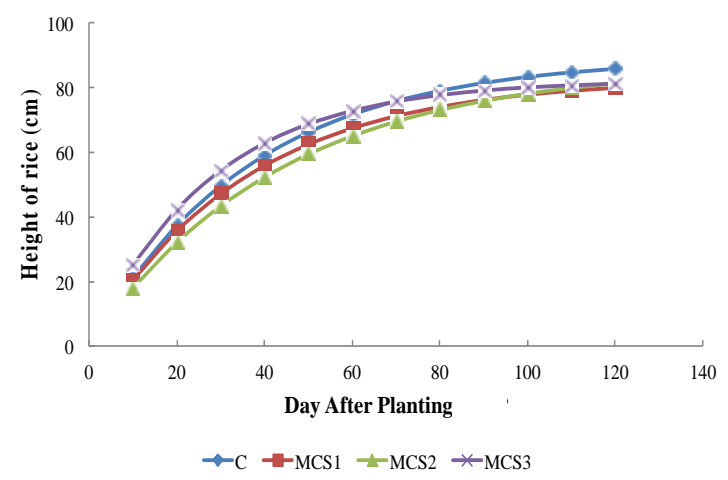

(b) Tanjungsari

Fig. 3 Height of rice in rice monoculture (C), rice-maize (MCS1), rice-cassava (MCS2) and rice-maize-cassava (MCS3) using monomolecular equation in Saptosari and Tanjungsari.

Table 2 Models of monomolecular function in the height of rice.

\begin{tabular}{llll}
\hline Field area & Treatments & Coefficient $(k)$ & $R^{2}$ \\
\hline \multirow{4}{*}{ Saptosari } & C & 0.027 & 0.687 \\
& MCS1 & 0.025 & 0.681 \\
& MCS2 & 0.026 & 0.819 \\
& MCS3 & 0.020 & 0.782 \\
\hline \multirow{3}{*}{ Tanjungsari } & C & 0.027 & 0.665 \\
& MCS1 & 0.028 & 0.811 \\
& MCS2 & 0.023 & 0.840 \\
\hline
\end{tabular}

Table 3 Models of exponential polynomial function in number of tillers.

\begin{tabular}{llllll}
\hline \multirow{2}{*}{ Field area } & \multirow{2}{*}{ Treatments } & \multicolumn{4}{c}{ Coefficients } \\
\cline { 3 - 6 } & & $\mathrm{a}_{0}$ & $\mathrm{a}_{1}$ & $\mathrm{a}_{2}$ \\
\hline \multirow{3}{*}{ Saptosari } & $\mathrm{C}$ & -0.003 & 0.549 & -5.545 & 0.885 \\
& MCS1 & -0.002 & 0.356 & -2.459 & 0.896 \\
& MCS2 & -0.002 & 0.383 & -2.361 & 0.774 \\
\multirow{3}{*}{ Tanjungsari } & MCS3 & -0.001 & 0.256 & -0.660 & 0.884 \\
& C & -0.009 & 1.423 & -21.062 & 0.866 \\
& MCS1 & -0.005 & 0.726 & -6.756 & 0.899 \\
\hline
\end{tabular}

Fig. 3 showed that the growth of rice was faster during the initial stage (10-40 d after planting), thereafter became slow and constant until final growth stage. It was indicated that the height of rice was higher in the vegetative phase and slow in the reproductive phase. Growth rate of rice resulted that monoculture had the highest value in Saptosari (Table 2). However, in Tanjungsari, the highest value was obtained in MCS (Table 3). The height of rice was not significantly different between monoculture and all combinations MCS1, MCS2 and MCS3. Small design of plots and closest row spacing caused the competitions of plants to get more nutrient, water and solar radiation for their growth and development.

\subsubsection{Number of Tillers}

The number of tillers per combination in Saptosari and Tanjungsari is shown in Fig. 4. Generally, number of tillers was increased during vegetative phase and decreased at the final growth stage due to ineffective tillers. The maximum number of tillers of rice in Saptosari was formed to revolve around the age of 100 d after planting (Fig. 4a). On the other hand, Fig. 4b showed the maximum formation of tillers in Tanjungsari occurs in growing phase, at the age of 80 $\mathrm{d}$ after planting. Different times of the maximum tillers formed were affected by planting date. 


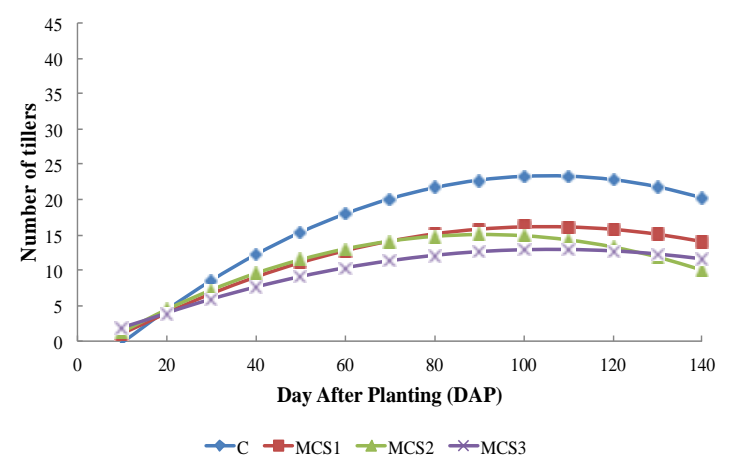

(a) Saptosari

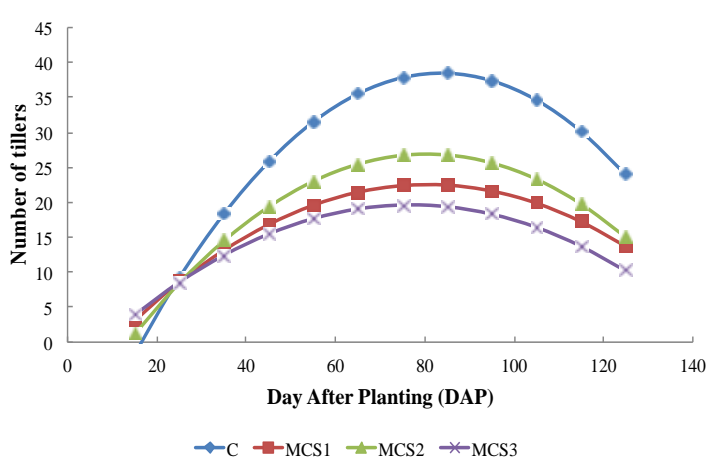

(b) Tanjungsari

Fig. 4 Number of tillers in rice monoculture (C), rice-maize (MCS1), rice-cassava (MCS2), and rice-maize-cassava (MCS3) using exponential polynomial equation in Saptosari and Tanjungsari.

Table 4 Rice crop index.

\begin{tabular}{lllll}
\hline Field area & Growth phase & Date & Plant age $(\mathrm{cm})$ & Crop index $(M)$ \\
\hline \multirow{5}{*}{ Tanjungsari } & Panicle initation & 29-Nov-2010 & 65 & 177.75 \\
& Heading & 09-Dec-2010 & 75 & 194.97 \\
& Flowering & 29-Dec-2010 & 95 & 226.55 \\
& Milk grain & $10-J a n-2011$ & 107 & 244.40 \\
& Dough grain & 18-Jan-2011 & 116 & 256.64 \\
& Mature grain & 28-Jan-2011 & 125 & 271.14 \\
\hline \multirow{5}{*}{ Saptosari } & Panicle initation & 09-Dec-2010 & 83 & 200.06 \\
& Heading & 19-Dec-2010 & 93 & 215.93 \\
& Flowering & 09-Jan-2011 & 114 & 247.16 \\
& Milk grain & 18-Jan-2011 & 123 & 260.82 \\
& Dough grain & 28-Jan-2011 & 133 & 275.26 \\
\hline
\end{tabular}

Fig. 4 shows exponential polynomial equations in number of tillers on the growth of rice, and the model is fit and represents the growth of rice based on height and number of tillers $(P<0.05)$. Fig. 4 also shows that the most optimum tillers formation is in monoculture, because of no competition in obtaining solar radiation or soil moisture. Sasmita [15] reported that productive tillers of rice were decreased, if the solar radiation was low. The growth of tillers number in Saptosari and Tanjungsari showed rice in monoculture had more tillers than in MCS.

\subsection{Effect of Different Cropping System on Crop Index}

In this study, the crop index was calculated based on different field area of experiment. Table 4 shows the value of crop index $(M)$ in different growth phases. The crop index value was increased by the time until the final growth stage. It was affected by the accumulation of solar radiation, which received by rice plant. Pusposutardjo [10] stated that crop index is the function of solar radiation.

Different values of crop index were affected by planting and harvesting time. Saptosari had higher value of $M$ than Tanjungsari due to long periods of plant cultivation.

\subsection{The Response of Rice Yield on Water}

Daily evapotranspiration (ETm and ETa) is shown in Fig. 5. Evapotranspiration is the parameter related with rice production. Soil water is readily available for the crop, if ETa equal with ETm [3]. Evapotranspiration was low in the early growth stage and then increased until vegetative growth stage and decreased at the final growth stage of rice. 


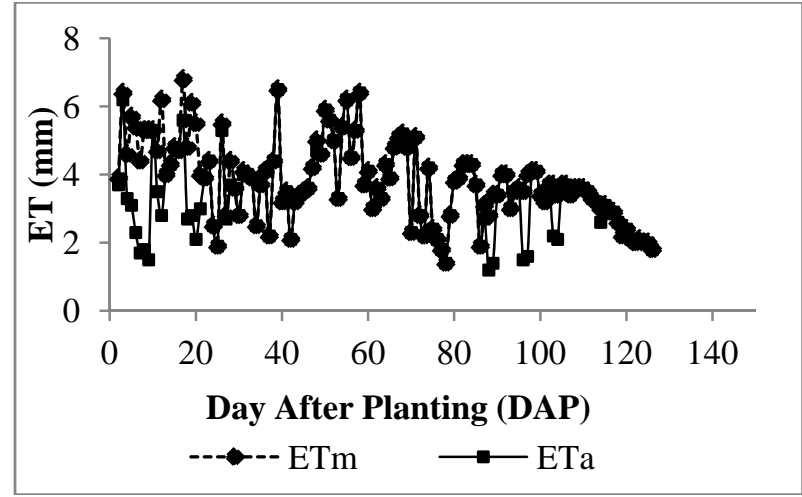

(a) Saptosari

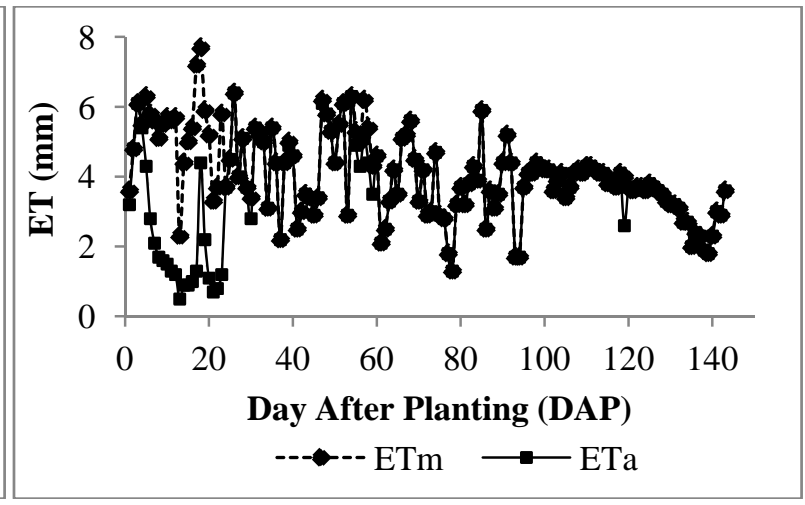

(b) Tanjungsari

Fig. 5 The ETm and ETa of rice in Saptosari and Tanjungsari .

Table 5 Total evapotranspiration of rice.

\begin{tabular}{lll}
\hline \multirow{2}{*}{ Field area } & \multicolumn{2}{c}{ Total evapotranspiration (mm) } \\
\cline { 2 - 3 } & ETm & ETa \\
\hline Tanjungsari & 479 & 433 \\
Saptosari & 590.2 & 513.8 \\
\hline
\end{tabular}

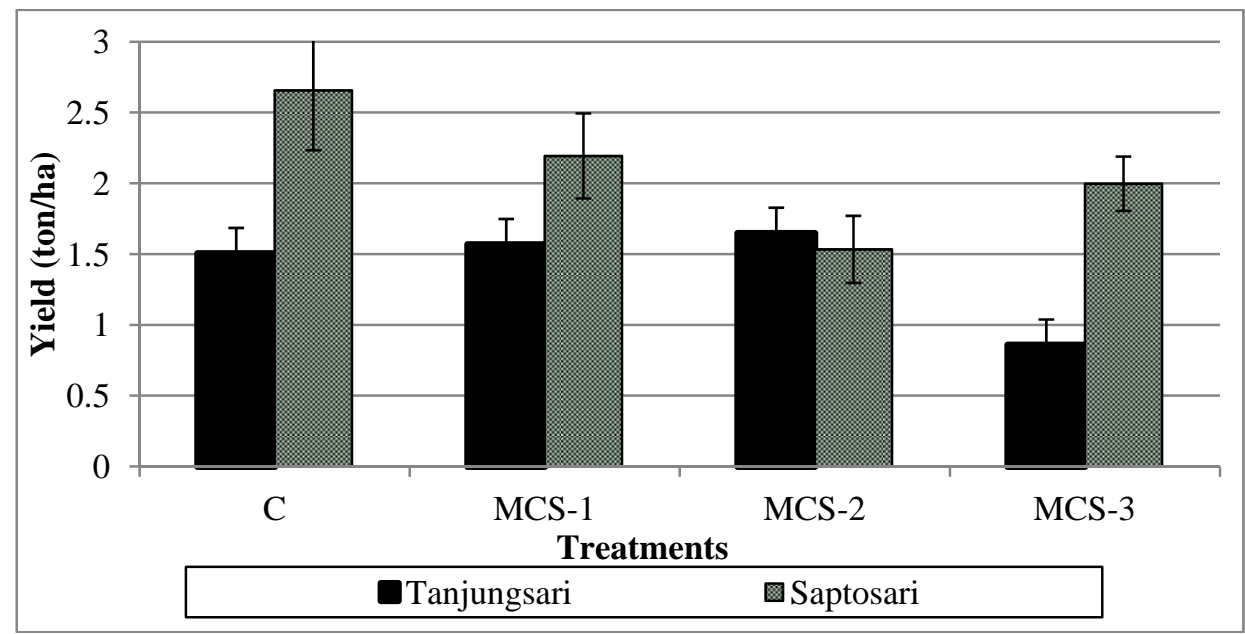

Fig. 6 Rice yield of monoculture (C), rice-maize (MCS1), rice-cassava (MCS2) and rice-maize-cassava (MCS3) in Saptosari and Tanjungsari.

Fig. 5 showed that ETa of rice in the early season was smaller than ETm $(E T a<E T m)$. The possible reason was due to low rain intensity. This condition affected water stress and resulted to most of the rice plant to die. Water stress in Saptosari occurred in the early and mid-seasons (Fig. 5a). On the other hand, in Tanjungsari, this occurred only in the early season (Fig. 5b). Commonly, intensity of water stress in Tanjungsari was higher than Saptosari. Water stress can have major impact on productivity and yield depending on timing, severity and duration [3]. In the early stage, the dead plants were replaced with new seeds. Total evapotranspiration in Tanjungsari and Saptosari are shown in Table 5. Saptosari resulted higher total ET than Tanjungsari.

Fig. 6 showed that rice yield at Saptosari was higher than at Tanjungsari. This was attributed to higher total ET at Saptosari (Table 5). Akinbile [2] reported that evapotranspiration has direct relationship with rice yield. Monoculture also showed higher yield than other treatments due to production of higher number of tillers. However, the effect of cropping 
system was not significant $(P>0.05)$. The present study expected that cropping system would affect rice growth and yield, but the obtained results were differed. Multiple cropping decreased the rice growth and yield due to competition of each crops. There are competition among different plants to get solar radiation and they affect on photosynthesis process. Further, multiple cropping also increased the competition between plants to absorb water and nutrients from the soil. This is in agreement with Goldsworthy and Fisher [16] and Herlina et al. [17].

\section{Conclusions}

The study has shown that rice plant height and number of tillers were not significantly affected by cropping methods $(P>0.05)$. However, monoculture treatment had more number of tillers than MCS. Crop index of rice on Saptosari was higher than Tanjungsari. Furthermore, water deficit was higher on initial than mid-season $(E T a>E T m)$ and affected water stress. Statistical analysis showed that cropping methods did not significantly affect rice growth and yield $(P>$ $0.05)$.

\section{References}

[1] Naylor, R., Falcon, W., Wada, N., and Rochberg, D. 2002. "Using El Nino-Southern Oscillation Climate Data to Improve Food Policy Planning in Indonesia.” Bulletin of Indonesian Economic Studies 38 (1): 75-91.

[2] Akinbile, C. O. 2010. "Crop Water Use Responses of Upland Rice to Differential Water Distribution under Sprinkler Irrigation System.” Advances in Applied Science Research 1 (1): 133-44.

[3] Steduto, P., Hsiao, T. C., Fereres, E., and Raes, D. 2012. "Crop Yield Response to Water." FAO Irrigation and Drainage Paper 66. Accessed June 2015. http://www.fao.org/docrep/016/i2800e/i2800e00.htm.

[4] Hoogenboom, G. 2000. "Contribution of Agrometeorology to the Simulation of Crop Production and Its Applications.” Agricultural and Forest
Meteorology 103 (1-2): 137-57.

[5] Doorenbos, and Kassam. 1979. "Yield Response to Water.” FAO Irrigation and Drainage Paper No. 33, FAO, Rome. Accessed March 12, 2015. http://www.fao.org/nr/ water/docs/irrigationdrainage66.pdf.

[6] Beets, W. C. 1975. "Multiple Cropping Practices in Asia and the Far East." Agriculture and Environment 2 (3): 219-28.

[7] Sitompul, S. M., and Guritno, B. 1995. Analysis of Plant Growth. Yogyakarta: Gadjah Mada University Press. (in Indonesia)

[8] Tao, F., Zhang, S., and Zhang, Z. 2012. "Spatiotemporal Changes of Wheat Phenology in China under the Effects of Temperature Day Length and Cultivar Thermal Characteristics.” European J. of Agronomy 43: 201-12.

[9] Zhang, S., and Tao, F. 2013. "Modeling the Response of Rice Phenology to Climate Change and Variability Indifferent Climatic Zones: Comparisons of Five Models.” European Journal of Agronomy 45: 165-76.

[10] Pusposutardjo, S. 1984. "Growth and Yield Modeling of Irrigated Soybean and Peanut in Tropical Rain Monsoon Climates.” Doctoral thesis, Utah State University.

[11] Agricultural Service for Food Crops and Horticulture, Gunungkidul District. 2009. Rainfall Database in Gunungkidul District.

[12] Agricultural Service for Food Crops and Horticulture, Gunungkidul District. 2006. Profil Tanaman Pangan Kabupaten Gunungkidul. (in Indonesian)

[13] Gomez, K. A., and Gomez, A. A. 1984. Statistical Procedures for Agricultural Research, 2nd ed.. Singapore: Wiley.

[14] Murtiningrum, W. A. P., Sewan, D. L., and Wardana, W. 2011. "Mathematical Models of Rice Tillers and Crop Height Growth of Rice Cultivated with SRI Method.” Journal of Agrotechnology 5: 92-107.

[15] Sasmita, P. 2006. "Growth Evaluation and Double Haploid in Production of Dryland Rice on Multiple Cropping System.” Buletin Agron. 34 (2): 79-86. (in Indonesian)

[16] Goldsworthy, P. R., and Fisher, N. M. 1984. The Physiology of Tropical Field Crops. Chichester: John Wiley.

[17] Herlina, N., Didik, and Isnaini, F. 1996. "The Influence of Harvest Time and Density of Lettuce to Growth and Crop Yield in Multiple Cropping System.” Agrivita 19 (2): 74-8. (in Indonesian) 